\title{
Formation of Dual Perceptions through Dual Treatments
}

\author{
Assoc. Prof. Dr. Svjetllana Kërënxhi \\ University of Elbasan, Albania, Faculty of Natural Sciences, Department of Mathematics \\ Email: skerenxhiel@yahoo.com
}

\author{
Assoc. Prof. Dr. Pranvera Gjoci \\ University of Elbasan, Albania, Faculty of Education Science, Department of Methodology of Teaching \\ Email: veragjoci@yahoo.com
}

\section{Doi:10.5901/mjss.2014.v5n20p1385}

\section{Abstract}

\begin{abstract}
In this paper, after the view on duality, we outline a new theoretical model in learning and teaching system, which includes dual treatments in elementary education and aims the formation of dual perceptions in students. The model was fostered by the ideas of Gray and Tall and then it develops in a new point of view making possible learning and teaching to be directed in such way that it will assist in formation of dual perceptions. The dual perceptions are described by adapting a model provided by Schön, and this means education of special skills among students. As an element that influences in a positive way in critical thinking, dual perception increases significantly the effectiveness of learning among students. We believe that this model will be an experience that will help teachers in their teaching process.
\end{abstract}

Keywords: critical thinking, duality, dual treatment, dual perception, learning, teaching

\section{Views on Duality}

Duality is not a new discovery in science, as knowledge come from antiquity. The following describes shortly some aspects of recognition of duality 'yesterday' and the evaluation that is made 'today'. These aspects are of interest to show the importance that takes our idea that the dual treatments should be included in the process of learning and teaching.

According to Gao (2000) the term duality as used in our daily life means the sort of harmony of two opposite or complementary parts through which they integrate into a whole. Gao describes duality in nature as follows:

"Duality in nature is amazingly beautiful, for it is the way nature was created. Duality in nature is simply mysterious, for it is the way that nature exists. It is beautiful because all things were originally created in a splendid harmonious world. It is mysterious because different creatures have different patterns of duality. If we are not confused very often about the duality of natural phenomena, we do not really understand what it is. This may be the way that we exist." (2000, p. xv)

Duality is the form and manner of existence of matter, legality of all processes of nature.

\subsection{Duality in philosophy and psychology}

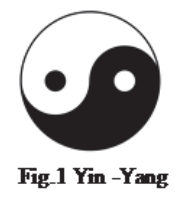

Since the ancient times in Chinese philosophy, the ancient emblem 'Yin - Yang' (Fig.1) which is the symbolism of the coexistence of opposites and change, had existed. According to Kincher (2008) this symbol shows that nothing is all good or all bad, all dark or all light, all happy or all sad; all things exist only in relation to their opposites and everything can become its opposite. Dual philosophical views of many scientists are very familiar. Thus, in the historical-philosophical analysis that Duka (1986) makes to the concept of interaction, it is supported by the point of view of Descartes and 
Newton, despite the different views between them, in which they unite in the idea that matter exists as well as thinking. Duka notes that it was this duality that confounded philosophical minds, especially about the issue how matter and thought interact, which are two substances independent of one another. In his study on characteristics of dual position and the conditions under which it is possible dualism in philosophy, Ivanov (2006) states that one of the strange features of cognitive philosophy of the second half of the twentieth century is the return of dualism in philosophy.

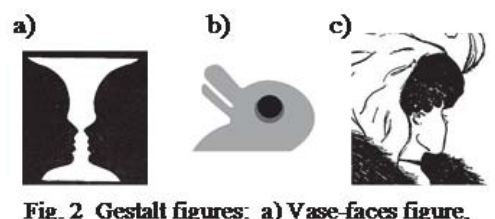

Fig- 2 Gestalt figures: a) Vase-faces figure,

b) Duck or rabbit, c) Old or young woman

Studies in psychology often point out the special ability that the human brain has in order to work separating periodically object once in one logical plan and then in a different one. To demonstrate this ability of the human brain Fisher (2005) and Pettijohn (1996) give the example of the gestalt figures (Fig.2). According to Schön (1993) the gestalt figures are used ordinarily to show how "the same figure" may be seen in very different, incompatible ways. Gestalt figures demonstrate in an obvious way the possible existence of dual attributes in the same object. One of gestalt figures that we find often is Vase-faces figure (Fig. 2a).

\subsection{Duality in mathematics}

In VI century BC, Pythagorean theory was based on the idea that numbers are the origin of all things. Laws of formation of numbers were considered as laws of the formation of things. The most important of these laws was, according to Pythagorean scientists, the duality 'odd number-even number'. This duality was taken as the basis of nine other dualities, which divided the world in two: 'limited-unlimited', 'one-many', 'right-left', 'male-female', 'light-shade', 'good-bad', 'mobileimmobile', 'straight-curved', 'square-rectangle' (Minga, 1988). Just as in the emblem 'Yin-Yang' or as in Vase-faces figure, these dualities express two opposite poles within the same object, two categories within the same display. Even today, it is acknowledge that the meaning of 'victory' cannot exist without the meaning of 'defeat', 'fast' without the meaning of 'slow', while in the field of mathematics there cannot exist the meaning of 'big' without the meaning of 'small', 'width' without the meaning of 'length', 'maximum' without 'minimum' etc. Gao (2000) writes that mathematics lies at the root of duality. Science of mathematics, as well as the other sciences, is characterized by an entity of the dual attributes. Yastrebov (2001) describes the dual attributes of mathematics classifying them into these dualities 'activityproduct', 'the individual-society', 'inductive-deductive', 'empiric-theoretical'. In the analysis that Aronov and Znamenskaya (2010) do to the "mathematical competence", they develop further the classification of Yastrebov adding to it the 'emotional-volitional' duality. Researchers emphasize that dual nature of the science of mathematics should be considered during its study as a school subject (Artstein-Avidan \& Milman, 2007; 1996; Yastrebov, Menshikova \& Yepifanova, 2006). For this problem Yastrebov states: "Dual properties of mathematics express its fundamental properties, which precisely because of their importance, should be understood in the process of its study" (2001, p. 53). In their article "Duality, ambiguity, and flexibility", Gray and Tall $(1991,1994)$ take in consideration the duality processconcept implemented in mathematics. They noted that the ambiguity of notation in mathematics allows the successful thinker the flexibility in thoughts to move between the process and the concept and they hypothesize that the successful thinker achieves this success in mathematics because it uses a mental structure which is an amalgam of process and concept. Gray and Tall called this amalgam 'procept'. They further developed their theory in Gray, Pinto, Pitta and Tall (1999).

\subsection{Duality in reflective practice and learning systems}

In the development of reflective practice and learning systems, Korthagen and Lagerwerf (1996) elaborated the model of three levels in which it offered an "integrating image" according to the model proposed by Schön (1993). They suggested the possibility of integrating the two viewpoints, which are learning and cognitive theory. Korthagen explains that the model is an elaboration of a theory on levels in mathematics learning developed by Van Hiele (1986), which in turn, is 
based on Piagetian notions about levels of cognitive development. Empirical data supporting the model were presented in Korthagen and Kessels (1999), and most extensively in Korthagen and Lagerwerf (2001). For their model Korthagen and Lagerwerf state that one important aspect of the realistic approach is that it builds on the notion of gestalts. In Korthagen (2010), the three-level model was summarized in a more holistic way of describing the relationship between teacher cognition and teacher behavior. According to Gao (2000) in the present day, the theory of duality has become a vast subject, especially due to the modern work in optimization, game theory, economic science, theoretical physics and chemistry, mathematical programming, variational analysis, nonconvex-nonsmooth analysis and control, critical point theory and in many other areas. By interrupting here the endless list of the occurrence of dualities, we emphasize that for sure the XXI century will give duality the value that it deserves.

\section{Dual Perceptions Based on Dual Treatments}

The ideas of Schön (1993) open new perspectives in the development of reflective practice and learning systems. In the "Generative metaphor" Schön presents important and influential new ideas about metaphor that have appeared in language acquisition, learning, scientific thinking and the creation of social policy. Metaphor described by Schön is linked with Vase-faces figure (Fig.2a). It has drawn the attention of researchers, some of whom (e.g. Korthagen \& Lagerwerf, 1996; Bereiter, 1997), have based their studies in this metaphor. It has been a known fact that if some people look at the Vase-faces figure for the first time some would see a vase, while others would see two profiles of people. Along this line, Schön (1993) introduced with another way of seeing it "as two profiles pressing their noses into a vase", a method which, as Schön explains, is achieved after people learn what is there to be seen. This metaphor that represents a model of 'a new integrating image' (Schön, 1993, p. 155-156, 163) is applied in our model of teaching where we describe the formation of dual perception.

Based also on the ideas of Gray and Tall $(1991,1994)$ we have outlined a new model of teaching that includes dual treatments about the formation of dual perceptions. It is believed that the formation of these perceptions among students has significant values in the process of learning; therefore, it should be included in the teaching process of mathematics and other subjects in school. Various authors (Gao, 2000; Yastrebov, 2001; Yastrebov, Menshikova \& Yepifanova, 2006; Artstein-Avidan \& Milman, 2007) provide their experience in the possibility of the involvement of the dual treatments in mathematics in secondary education and university level. Adjustment of dual mathematical treatments even for the level of students in elementary education became the object of studies (Gjoci \& Kërënxhi, 2010; 2012; 2013; Kërënxhi \& Gjoci, 2013). The thinking in general is addressed towards the things that are not known. A person is curious and he wants to learn about everything. We believe that this exact tendency, which may be encouraged during the process of learning of mathematics for the formation of dual perceptions, should be combined with the ability to learn the mathematic theory and exercises, viewing them in a dual point of view. This is possible to be realized in mathematics due to its dual character.

\subsection{Favorable situation}

The study was incited by a number of national projects applied in Albania that started with the project: 'Project for Development of Education in Albania' by AEDP-1997, which lasted three years. It included as its sub-project: 'Development of creative and critical thinking' by AEDP-1998. It was later extended with the project: 'Improvement of the quality of teaching and learning in Albania' by AEDP-1999, which lasted about a year including other smaller projects in terms of distribution and participation. This study was initiated by following this road opened by the application of these projects. The researchers tried to implement the experimental phase, which was related to study of the formation of dual perceptions during the school year 2009-2010. At this stage, they engaged in elementary education for teachers, who had a good experience of participation in projects on the experimentation of new teaching techniques and who quickly adapted to the techniques of dual treatments. To evaluate the effectiveness of the implementation of the model, the said teachers were observed and interviewed and chose two separate cases, 48 students of ages 7, 8, 9 and 10 years old who were selected in classes where the study was conducted.

\subsection{A new model of teaching}

This model is based on the model of Gray and Tall (1991) for the duality between process and concept in mathematics in the model of 'integrating image' proposed by Schön (1993). Their models had been incorporated in the present investigation by treating these models in a different standpoint. 


\title{
2.2.1 Theoretical Model
}

In duality concept-process of Gray and Tall (1991), 'procept and proceptual facts' had been focused and had been treated them in two different angles. The formation of dual perceptions as the ultimate achievement of the model had been considered too. The formation of dual perception means that the students are enabled to perceive 'integrating image'. This means that just like some people who acquire such skills to see both images simultaneously in the Vasefaces figure, students should also be trained to recognize the existence of the two categories, or in other words, the existence of duality within the same appearance, which may be a concept, exercise or problem. Creation of such skills among students was the first application in the inclusion of dual treatments in elementary mathematics. But what do we understand with the saying: dual treatment in elementary mathematics?

With the dual treatment in mathematics in elementary education, a special way of interpretation, analysis, formulation or solution that is made respectively to the concept, exercise or problem that carries with in itself a dual nature was utilized.

To clarify the model used, the mathematics of elementary education was referred; however, this model can be successfully applied in other subjects.

\subsubsection{Dual treatment of concepts}

Concepts are represented by symbols, while the symbols act dually as process and concept. To further clarify this statement we refer to Gray and Tall who state:

\begin{abstract}
"The ambiguity of notation allows the successful thinker the flexibility in thought to move between the process to carry out a mathematical task and the concept to be mentally manipulated as part of a wider mental schema. Symbolism that inherently represents the amalgam of process/concept ambiguity we call a 'procept'. We hypothesize that the successful mathematical thinker uses a mental structure that is manifest in the ability to think proceptually." (1994, p. 116).
\end{abstract}

In addition to the ambiguity of notation, which allows the student to 'think proceptually', another model of the ambiguity of notation which allows students to handle this symbol under the dual standpoint with the aim of forming dual perception was provided.

Here are some examples

1. The 'bigger' concept and the 'smaller' concept, which are accompanied by corresponding symbols, are a display of the existence of duality in the concepts of mathematics because when we say that a number is bigger than another number, in the same time the second number is smaller than the first number.

2. When we say that the segment $[A B]$ is longer than the segment $[C D]$, at the same time segment $[C D]$ is shorter than the segment $[A B]$.

3. A triangle is called a right-angled triangle if it has an angle equal to $90^{\circ}$, and if in a triangle we recognize that one of its angles is $90^{\circ}$ then immediately we stated that it is a right-angled triangle.

To achieve the creation of dual perception among students, the teacher must teach them that when given to a student the inequality, students should see it once on one side and once on the other side of the sign of inequality. This flexibility of seeing the problem makes that after a sufficient number of teaching sessions, students gain the special ability of seeing simultaneously the two relations: 'bigger', 'smaller'. That is to say, if students are given an inequality, for example $3>2$, in their mind should come immediately to two ways: ' 3 is bigger than 2 ' and ' 2 is smaller than 3 '. It can be described in an analogue way even the procedures for the other examples, therefore, after a practice directed by teachers, when talking about the comparison of segments in the minds of students, should arrive in their mind at the same time the two relations 'longer', 'shorter' or when we speak of right-angled triangle, in their minds should immediately spark the feature of having an angle $90^{\circ}$. Only after students have acquired the skills described above, one can say that the concepts addressed, 'bigger', 'smaller'; 'longer', 'shorter'; 'right angle', ' $90^{\circ}$ ' as dual property of the relations of comparison respectively of the set of numbers, and segments and figures is achieved the creation of dual perceptions.

\subsubsection{Dual treatments of exercises and problems}

Gray and Tall state: "... we consider the duality between process and concept in mathematics, in particular, using the same symbolism to represent both a process (such as the addition of two numbers $3+2$ ) and the product of that process (the sum 3+2)" (1994, p. 116). As following, numerical equation $3+2=5$ is treated by them as 'proceptual' fact that can 
produce new 'proceptual' facts. We think that the inclusion of dual treatments in the moment of provision of the process of summery or other mathematical operations, it facilitates the transition to the new 'proceptual' facts. Examples of dual treatments:

1. "The symbol $5+4$ represents both the process of adding through counting all or counting on and the concept of sum ( $5+4$ is 9 )" (Gray \& Tall, 1994, p. 120). Numerical equality $5+4=9$, which keeps on the left side the process described by Gray and Tall, while keeps on the right side the result of the sum, should be treated in a dual way. This means that it should be treated as an equality that is shown as the sum of the numbers 5,4 is 9 , and 9 disassembled as the sum of two numbers 5,4 .

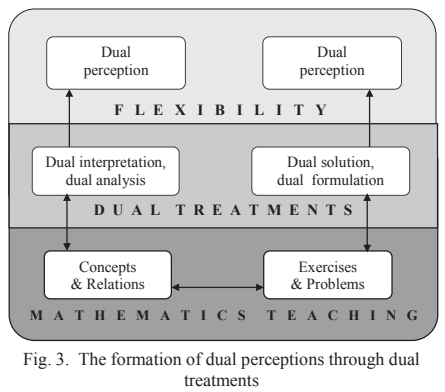

2. "The symbol $3 / 4$ stands for both the process of division and the concept of fraction" (Gray \& Tall, 1994, p. 120). To gain a clearer perception of the division process and the fraction concept, dual treatment should accompany the process for the formation of the concept of division. As a result the dual interpretation associated with the procedure of division should be: when the second number divides the first, at the same time the first number is divided by the second number.

3. The experience shows that the creative thinking skills are increased when solving of the problem is associated with the dual formulation. Dual formulation includes the main problem and the opposite problem or dual problem. Let's give an example of the formulation of dual problem: Anna is 23 years. Genta is 2 years younger than Anna. How old is Genta? Dual formulation: Anna is 23 years. She is 2 years older than Genta. How old is Genta?

To understand better the formation of dual perceptions through dual treatments we present it in Fig. 3.

\section{Capacity Building of Teachers in Order to Implement the Model}

It is recommended that these strategies from the present investigators did not intend to change the curriculum content, but just the way how it will be applied to the students. By cautious study of mathematics textbooks for grades 1-4, (Dedej et al., 2009a,b,c,d), it was concluded that they generally contain examples that teachers could do dual treatments. However, they had quite a few shortcomings of presenting the models which if they were included in the textbook would have created better opportunities for teachers and students to use dual treatments, consequently it was a task for teachers to fulfill this lack of the text. Despite the interviews and surveys done with teachers, some observations helped the researchers better understand the inadequacy of teachers in the understanding of duality.

Teacher Ina: From the observation of the third grade class on the topic of 5.3, it was learned that teacher Ina understood the duality of the problem only in the solution of the problem in two different ways. From the thorough study of curricula conducted, it was known that third-grade program required that for problem solving did not show how students should be trained to look at things from different angles (Dedej \& Frashëri, 1986). Teachers about the requirements of the program and arrived to the conclusion that as long as the problem except dual solution accepted even the dual formulation, then its dual formulation could be included in lesson.

Teacher Bona: From the observation of the fourth grade class on the topic of 5.8, it was noted that teacher Bona accepted as dual the opposite problem of the given problem. Without underestimating the importance of the opposite problem, the researchers discussed with the teacher the fact that the opposite problem of a problem is one aspect of dual formulation meanwhile the other aspect is the dual problem.

Taking into consideration the study of curricula, gathered information from interviews and observations made in a 
class hour, the concepts, exercises and problems that accepted the dual treatment, into three main groups were separated:

- In the first group, models with which teachers did not face difficulties for dual treatment were included

- In the second group, models where teachers faced partially difficulties in dealing with their dual treatment were considered.

- In the third group, models which teachers can not treat from the dual standpoint, but that in the following hours of teaching mathematics they should be treated as such once they carried a dual nature were noted.

At this stage, the researchers built their work on the basis of the individual in such a way that they could assist the teachers to overcome as soon as the difficulties faced with models of the second and third groups. After this phase, the results were felt especially in the observations that were made in the last months of the school year. In the observed hours, it was noticed that there was a significant improvement of the teaching of teachers, optimism and security. But what is the foremost important one, these elements were not seen only in teachers but also among students, few of whom had already won dual perceptions.

We are giving two of the interviews, done with the teachers.

Teacher Ina: "I am now quite happy with myself and with my students. We have clear dual treatments and discuss it together freely for new opportunities. We try to apply it not only in mathematics but also in other subjects."

Bona, fourth grade teacher, which in the first observation accepted as dual problem of a given problem only its opposite problem, in the topic of lesson 7.8 she built in collaboration with the students an example that included: the problem, the opposite of the given problem, and their two dual problems. Solutions to these problems were done by students.

\section{Dual Perceptions among Students}

The other aspect that the researchers were interested to learn was how much the students have benefited from this, how much they were influenced by the dual way of learning mathematics. To receive an answer about this problem, students who participated in the study and some students of parallel classes were tested and their answers were compared.

In testing done in 12 selected students in two first parallel classes this exercise was given: write as many equality and inequalities with the numbers 2, 5, 7. Do you notice any connection between the inequality $5>2$ and $2<5$ ? By comparing the given answers of students from both classes was noted that the students of the experimental class gave more complete answers than the students of the non experimental class. For example, in the non experimental class we observed that students wrote equation $2+5=7(100 \%)$, and generally was lacking the equation $7=2+5(34 \%)$. Equation $7=2+5$ was found written without defaults $(100 \%)$ in the students of the experimental class. In terms of description that has to do with the relation that exists between the two given inequality, students of the experimental class answered almost unanimously that is the same inequality but read in two different ways (83\%), whereas students of non experimental class partially answered same way, only $34 \%$ of students.

In testing done in 12 selected students in two second parallel classes, this problem was utilized: Problem 1. Anna bought 26 notebooks. Bora bought 8 notebooks less than Anna. How many notebooks have the two girls bought together? Requirements:

a. Create a scheme for solving of the Problem1.

b. Solve the Problem 1.

c. Maintaining the records of the Problem 1, formulate a new problem, Problem 2, which is solved the same way as the Problem 1.

d. Build scheme for solving Problem 2 that you formulated and solve Problem 2.

The students were divided into groups and we waited for their written responses. Students of the experimental class gave more completed answers.

At the end of the school year, the teachers of the experimented class were interviewed regarding topics of lessons for which they had applied the dual treatments, for the number of classes hours for the new concepts or skills training in which teachers and students have made dual interpretations; as well as for the amount of class hours in which problems were implemented with dual formulation or solution of the dual problems. They have given this data: they had managed to implement a dual treatment up to $30 \%$ of the teaching subjects, in $34 \%$ of class hours they had used new concepts and reinforcement of skills and $27 \%$ of hours with problem solving. In the Graph 1 there is shown the implementation of dual treatments, of concepts' interpretation and dual analysis, of dual solving and formulation of exercises and problems from 
the teachers of 1-4 grades.

Graph 1. Implementation of dual treatments: dual interpretations and analyses and dual solutions and formulations in teaching

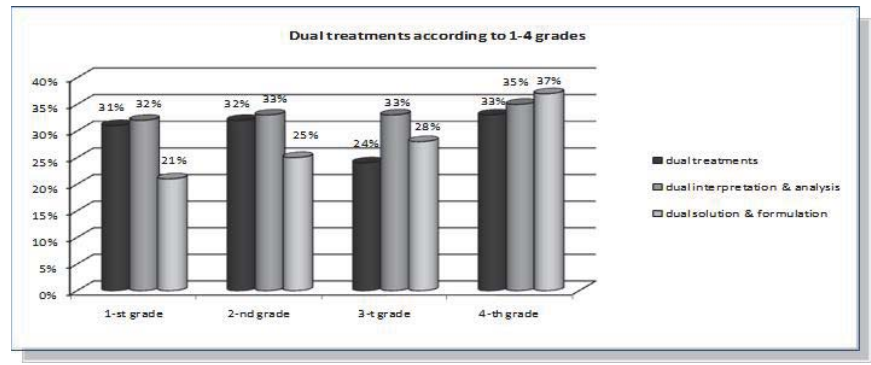

Indicators of experimental classes on gaining of the concepts and themes that carried dual treatment, compared to the non experimental classes, were encouraging. Interest and desire of students of different levels of learning mathematics marked a step forward. Concerning the experimental program it covered, where we saw opportunities, involvement with dual treatment of concepts, processes and 'proceptual' facts without giving teaching overload. Selected models were used by teachers in mathematics classes to develop in students an important aspect of critical thinking, especially in the ability to see issues in duality, the skill which is also called integrating perception.

\section{Conclusions}

Founder of 'Philosophy for children' Matthew Lipman presents a particular conception about critical thinking of children build by him that gives a good experience for teachers of lower grades of elementary education. He characterizes critical thinking as thinking that facilitates judgment, relies on criteria, is self-correcting, and is sensitive to context (Lipman, 2003). Experience and opinions given by researches of psychology, philosophy and education (Anderson et al., 1985; Resnick, 1987; Bonk \& Smith, 1998; Palincsar \& Brown, 1989; Paul, 1992; Kuhn, 1999; Facione, 2000; Van Gelder, 2005) bring to the conclusion that learning of students can be extended when the teacher can use a variety of thinking strategies and when students have the possibility to apply the new way of learning in new tasks. Lewis and Smith (1993) argue that critical thinking skills are for everyone, not just the gifted. According to the Temple et al., (2006), when that the student learns in an active way, it means that this student shows curiosity, asks questions, discovers new things, and uses his knowledge for problem solving. However, to reach the critical thinking, students should see the issues in different points of view, explore nuances of the consequences of ideas, and maintain an attitude based on reason. In this context the dual treatments, as activities that lead to the formation of dual perceptions, are considered as a practice that contributes to the realization of critical thinking. If students are taught to learn actively, looking at issues under dual point of view, they will be prepared for the day when school would end and they would need to continue to self learn during all their lives. In order to reach the level of critical thinking, through dual treatments we recommend to be considered Yastrebov (2001), who states that in the process of mathematics learning the teacher should have a big amount of problems according to the all topics that the course studies, which form the students with the vision of dual properties of mathematics.

Until now, the present investigation indicates that the inclusion of dual treatment in the process of learning mathematics in elementary education significantly affects the growth rate of an understanding of this subject, leading students to the formation of dual perceptions and development of critical thinking. We think that dual treatments may be included in the mathematical teaching starting from the first grade of the elementary education. The concepts of the quantity, length and number may be learned starting from the dual interpretation of the oppositions: many-few, long-short, bigger than-smaller than. Meanwhile empirical evidence is necessary to confirm it and this is our aim in the future. However at this moment we clarify the reader through the Egan's (1998) words, who states that the educational point is not to teach binary concepts, nor to teach that the world is structured in binary terms, but always to lead toward mediation, elaboration, and conscious recognition of the initial structuring concepts. The dual treatments may be gradually extended into the dual interpretations, dual analyses, dual solutions and dual formulations. If the students get used to a structure, based on dual treatments, then dual perceptions are formed in them. Actually people tend to group 
the triggers according to rules and principles. This grouping of the particular sense triggers in a single entity - a complex model we call integrating perception. In this paper we call these structures integrative perceptions. Students should be guided toward the formation of integrating perceptions. This will be possible when they achieve different points of view about the mathematical situations.

\section{References}

Anderson, R. C., Hiebert, E. H., Scott, J. A., \& Wilkinson, I. A. G. (1985). Becoming a nation of readers: The Report of the Commission on Reading. Urbana, IL: University of Illinois.

Artstein-Avidan, Sh., \& Milman, V. (2007). A characterization of the concept of duality. Electronic Research Announcements in Mathematical Sciences, 14, 42-59.

Aronov, A. M., \& Znamenskaya, O. V. (2010). On the notion of "mathematical competence", Bulletin of Moscow University. MV Lomonosov (in Russian) 20(4), 31-43.

Bonk, C. J., \& Smith, G. S. (1998). Alternative instructional strategies for creative and critical thinking in the accounting curriculum. Journal of Accounting Education, 16(2), 261-293.

Bereiter, C. (1997). Situated cognition and how to overcome it. In D. Kirshner, \& J. A. Whitson (Eds.), Situated cognition: Social, semiotic, and psychological perspectives (pp. 281-300). Mahwah, NJ: Lawrence Erlbaum Associates.

Dedej, K., \& Frashëri, A. (1986). Matematika 3: tekst për mësuesin. Tiranë: SHBLSH.

Dedej, K., Spahiu, E., \& Konçi, Z. (2009a). Matematika 1: për klasën e parë të shkollës 9-vjeçare. Tiranë: SHBLSH e Re.

Dedej, K., Spahiu, E., \& Konçi, Z. (2009b). Matematika 2: për klasën e dytë të shkollës 9-vjeçare. Tiranë: Print 2000.

Dedej, K., Spahiu, E., \& Konçi, Z. (2009c). Matematika 3, për klasën e tretë të shkollës 9-vjeçare. Tiranë: SHBLSH e Re.

Dedej, K., Spahiu, E., \& Konçi, Z. (2009d). Matematika 4, për klasën e katërt të shkollës 9-vjeçare. Tiranë: Albtipografia.

Duka, S. (1986). Vështrim historiko-filozofik mbi konceptin e bashkëveprimit. Matematika dhe fizika në shkollë, 11, 92-108.

Egan, K. (1998). The Educated Mind: How Cognitive Tools Shape Our Understanding. University of Chicago Press.

Facione, P. A. (2000). The disposition toward critical thinking: Its character, measurement, and relation to critical thinking skill. Informal Logic, 20(1), 61-84.

Fisher, R. (2005). Teaching children to think, (2nd ed.). Cheltenban: Nelson Thornes.

Gao, D. Y. (2000). Duality principles in nonconvex systems: Theory, Methods and Applications. Boston/Dordrecht/London: Kluwer Academic Publishers.

Gray, E., Pinto, M., Pitta, D., \& Tall, D. (1999). Knowledge construction and diverging thinking in elementary \& advanced mathematics. Educational Studies in Mathematics, 38(1-3), 111-133.

Gray, E. M., \& Tall, D. O. (1994). Duality, ambiguity, and flexibility: A proceptual view of simple arithmetic. Journal for Research in mathematics education, 26(2), 115-141.

Gray, E. M., \& Tall, D. O. (1991). Duality, ambiguity, and flexibility in successful mathematical thinking. In F. Furinghetti (Ed), Proceedings of the $13^{\text {th }}$ Conference of the International Group for the Psychology of Mathematics Education, Vol 2 (pp. 72-79). Assisi, Italy.

Gjoci, P., \& Kërënxhi, S. (2010). Dual interpretations in primary education mathematics as aspect of critical thinking of students. Odgojne Znanosti - Educational sciences. 2(20), 413-426.

Gjoci, P., \& Kërënxhi, S. (2012). Efektet e modelit Intuita Gestalt në mësimdhënie. Buletini i Shkencave Natyrore, FSHN, UT, 14, 15-26.

Gjoci, P., \& Kërënxhi, S. (2013). Duality and the importance of dual treatments' inclusion in teaching. Journal of Education \& Social Research, 7(3), 631- 638.

Heyman, G. D. (2008). Children's critical thinking when learning from others. Current Directions in Psychological Science, 17(5), 344347.

Ivanov, D. V. (2006). Dualism and Qualia. Вестник Московского университета, (in rusian) 7(2), 3-21.

Kërënxhi, S., \& Gjoci, P. (2013). A new methodical treatment for math teaching and its effect on math learning. Journal of Education \& Social Research, 7(3), 662- 670.

Kincher, J. (2008). Psychology for kids: 40 fun tests that help you learn about yourself Minneapolis, (3rd ed.). MN: Free Spirit Publishing.

Korthagen, F. A. J. (2010). Situated learning theory and the pedagogy of teacher education: Towards an integrative view of teacher behavior and teacher learning. Teaching and Teacher Education, 26, .98-106.

Korthagen, F. A. J., \& Kessels, J. P. A. M. (1999). Linking theory and practice: changing the pedagogy of teacher education. Educational Researcher, 28(4), 4-17.

Korthagen, F., \& Lagerwerf, B. (2001). Teachers' professional learning: how does it work? In F. A. J. Korthagen, J. Kessels, B. Koster, B. Lagerwerf, \& T. Wubbels (Eds.), Linking practice and theory: The pedagogy of realistic teacher education (pp.175-206). Mahwah: Lawrence Erlbaum Associates.

Korthagen, F. A. J., \& Lagerwerf, B. (1996). Reframing the relationship between teacher thinking and teacher behaviour: levels in learning about teaching. Teachers and Teaching: Theory and Practice, 2(2), 161-190.

Kuhn, D. (1999). A developmental model of critical thinking. Educational Researcher, 28(2), 16-26.

Lewis, A., \& Smith, D. (1993). Defining higher order thinking. Theory into Practice, 32(3), 131-137.

Lipman, M. (2003). Thinking in Education, (2nd ed.). New York: Cambridge University Press.

Minga, A. (1988). Leksione për probleme të përgjithshme në matematikë. Çështje të historisë së mendimit matematik (1). Tiranë: 
Shtypshkronja e Dispencave.

Paul, R. W. (1992). Critical thinking: What, why, and how? New Directions for Community Colleges, 1992(77), 3-24.

Palincsar, A.S., \& Brown, A.L (1989). Instruction for self-regulated reading. In L. B.Resnick \& L.B.Klopfer (Eds.), Towards the thinking curriculum: Current cognitive research. (pp. 19-39). Arlington, Alexandria, VA: Association for Supervision and Curriculum Development.

Pettijohn, T. F. (1996). Psikologjia - Një hyrje koncize (2nd ed.). (in albanian) Tiranë: Lilo.

Resnick, L. B. (1987). Education and learning to thlnk. Washington, DC: National Academy Press.

Schön, D. A. (1993). Generative metaphor: a perspective on problem-setting in social policy. In A. Ortony (Ed.), Metaphor and Thought (2nd ed.) (pp. 137-163). Cambridge: Cambridge University Press.

Temple, C., Crawford, A., Saul, W., Mathews, S., \& Makinster, J. (2006). Strategji të mësimdhënies dhe të të nxënit për klasat mendimtare, udhëzime për trajnuesit (in albanian). Tiranë: QAD.

Van Gelder, T. (2005). Teaching critical thinking: Some lessons from cognitive science. College Teaching, 53(1), 41-48.

Van Hiele, P. M. (1986). Structure and insight: A theory of mathematics education. Orlando: Academic Press.

Yastrebov, A. V. (2001). Dualistic properties of mathematics and their reflection in the process of teaching. Yaroslavl Pedagogical Gazette, (in Russian) 1, 48-53.

Yastrebov, A. V., Menshikova, N. A., \& Yepifanova, N. M. (2006). Identifying dualistic properties of science in the process of teaching in elementary mathematics. Yaroslavl Pedagogical Gazette, (in Russian) 4, 87-93. 